Article

\title{
Effect of COVID-19 on International Trade among the Visegrad Countries
}

\author{
Erginbay Ugurlu ${ }^{1}$ and Irena Jindřichovská ${ }^{2, *}$ (D) \\ 1 Department of International Business, Metropolitan University Prague, Dubečská 900/10, Strašnice, \\ 10031 Praha, Czech Republic; erginbay@gmail.com \\ 2 Department of Financial Management, Metropolitan University Prague, Dubečská 900/10, Strašnice, \\ 10031 Praha, Czech Republic \\ * Correspondence: irena.jindrichovska@mup.cz
}

Citation: Ugurlu, Erginbay, and Irena Jindřichovská. 2022. Effect of COVID-19 on International Trade among the Visegrad Countries. Journal of Risk and Financial Management 15: 41. https:// doi.org/10.3390/jrfm15020041 Academic Editors: Thanasis Stengos and Shigeyuki Hamori

Received: 27 November 2021

Accepted: 12 January 2022

Published: 19 January 2022

Publisher's Note: MDPI stays neutral with regard to jurisdictional claims in published maps and institutional affiliations.

Copyright: (C) 2022 by the authors. Licensee MDPI, Basel, Switzerland. This article is an open access article distributed under the terms and conditions of the Creative Commons Attribution (CC BY) license (https:// creativecommons.org/licenses/by/ $4.0 /)$.
Abstract: The impact of the COVID-19 pandemic has been detrimental to all countries, despite the continuous efforts of governments on all continents to attempt to mitigate its damaging effects. All economic and social indicators have worsened. This study explores the impact of COVID-19 on international trade among the Visegrad Four (V4) countries. We employ data from Eurostat and FRED to explore this influence, using the monthly import and export data for the 2010 M1-2021 M4period. We estimate the trade model for each member country of the V4, exploring their trade relations with other V4 members. We employ a shift dummy and impulse dummy to show the effect of country lockdowns initiating possible structural change. After exploration, we found that the COVID-19 impact was evident in all countries, but not with the same strength. Looking outside the V4 group, we can also see that there are strong trade relations with Germany, which is the strongest European economy. For further exploration, we suggest investigating these outside links to complete the picture.

Keywords: COVID-19; Visegrad Four; international trade; ARDL model

\section{Introduction and Background}

The aim of our study is to capture the impact of the harmful COVID-19pandemic on international trade among the Visegrad Four. International trade has declined worldwide by eight per cent compared to 2019 (UNCTAD 2021), but the impact was not the same in all regions. In this study, we concentrate on the block of four countries in Central and Eastern Europe that became a part of the EU in 2004. The V4 countries developed under the specific conditions of centrally planned economies after the Second World War. The Visegrad Four (V4) was established on 15 February 1991, in Visegrad, Hungary, by the presidents of Czechoslovakia, Poland, and Hungary. (After the split of Czechoslovakia, there were four members of this block), see Visegrad Group History ${ }^{1}$. The purpose of this block was to coordinate their efforts within the EU. In this study, we attempt to discover whether this specific background has an impact on the development of these four countries in these specific crisis conditions. The V4 countries form a formal political block with a rotating chair and use a common Visegrad fund to finance their further development. The countries also weakly follow some common economic goals, albeit with varied success (Cabada and Waisová 2018; Cabada 2018). Historically, after the Second World War, there was a common political alliance between these countries within the so-called COMECON (the Council for Mutual Economic Assistance). This organization was established in January 1949 to facilitate and coordinate the economic development of East-European countries. Politically, the countries were part of the Warsaw Pact (Grzybowski 1971; Thomas 1976).

Thirteen years after COMECON ceased to exist in 1991, the V4 countries joined the EU (in May 2004) together with six other Central and East-European states (Henderson 2005; 
Schimmelfennig and Sedelmeier 2005). Before this activity, there was also an initiative to collaborate under the auspices of CEFTA. Nowadays, the V4 can be understood as a more or less formal political block, which does not have any strictly defined economic policy. However, the V4 attempts to promote the region's common interests within the EU. In this vein, the V4, together with other post-communist countries, plus Greece and Portugal, instigated an EU-wide initiative of seven-year financial plans. Despite this, the position of this sub-block is not very strong or dominant in Europe. It seems that the countries within the block enjoy "too big a freedom" when it comes to pursuing commonly agreed goals. The countries are politically, and even more economically, undecided whether to follow the West European states or collaborate more with Russia and China. This is visibly the case in Hungary (Waisová 2020). All in all, the V4 countries prefer to pursue their individual interests, including economic policy (de Liedekerke 2015; Hanus and Vácha 2020; Kazharski 2020; Mazur and Banach 2021).

The study contributes to the literature exploring empirical application testing by investigating the effect of COVID-19 on international trade. Furthermore, we investigate the type of the effect by using impulse and shift dummies. The third contribution of our paper is to the modeling of international trade between the Visegrad countries by using the ARDL model.

The paper is organized as follows: Section 1 is the introduction. Section 2 provides a literature review, including the impact of COVID-19 on international trade. Section 3 describes the trade among the four countries, and Section 4 introduces a brief review of the used data. Section 5 explains the models and our empirical approach. Section 6 shows the results, and Section 7 presents the conclusions and a discussion.

\section{Literature Review}

\subsection{International Trade in the V4}

The set of papers published by Smutka et al. (Svatoš and Smutka 2010, 2012a, 2012b; Svatoš et al. 2010; Vološin et al. 2011) analyzed trade with agricultural commodities and explored the territorial structure and competitiveness of the agricultural trade of the Visegrad Group in 1993-2008. The authors found that there has been a significant increase in the volume and value of traded agricultural products. The territorial structure of exports and imports has concentrated on the trade with the countries of the EU27. Their accession to the EU in 2004 was favorably reflected in the agricultural trade results, especially in the case of Poland. Nevertheless, even in the case of the Czech Republic and Slovakia, the accession did not impair the results in the area of agricultural trade. Serious structural problems in the agricultural sector after EU accession occurred only in Hungary. Nevertheless, it can be argued that these problems could be attributed to Hungary's current economic problems.

Babunek (2012) investigated the inflow of foreign direct investment per capita in the countries of the Visegrad Four and their most important trading partners using analyses of variance (ANOVA). He found significant differences between the countries. However, after including Germany and Austria, he found that these countries form a compact unit in terms of FDI per capita. Richter (2012) analyzed the changes in trade between the V4 after the group entered the EU based on SITC commodity groups. He established that there was an aggregate upturn in the mutual trade of the region's countries; intra-Visegrad trade has risen. However, the commodities structure has not changed significantly. The author identified the important role of foreign-owned enterprises in the V4 countries, and he attributed the rise to their presence. The paper shows that the EU accession has not brought about many abrupt changes in commodity patterns. Furthermore, the effect is not focused on the year of accession but is more or less spread over the period before the accession. The Visegrad region is thought to have been upgraded both as a target for sales and a producer having a host of potential cooperation production partners.

Ugurlu and Jindrichovska (2019) tested the gravity models using trade variables and FDIs, as well as the impact of local culture represented by the gradual acceptance of IFRS. The gravity model was significant in the Czech Republic. Furthermore, Kowalska et al. 
(2021) explored the competitive position of the V4 in the agri-food segment focusing on the international competitive position of the V4 countries. The V4 countries' accession to the EU significantly changed the exporters' and importers' situation in these countries, providing them with better access to numerous markets. The authors conclude that Poland performed the best in international trade in agri-food products among the V4 countries. Similar results were also confirmed in relation to the Czech Republic (Smutka et al. 2016, 2018).

\subsection{Impact of COVID-19}

Based on the International Monetary Fund (IMF) (2021) data, the first case of COVID19 was reported on 1 March 2020 in Czech Republic, 4 March 2020 in Hungary and Poland, and 6 March in Slovakia. Many papers investigate the impact of COVID-19 on trade (Cvik and Pelikánová 2021; Jindřichovská and Uğurlu 2021) and consumption (MacGregor Pelikánová and Hála 2021).

Czech et al. (2020) explored the short-term reaction of the financial markets of the V4 to the COVID-19 pandemic. The authors have used the exchange rates of local currencies to EUR on the major stock markets Prague PX, Budapest BUX, Warsaw WIG20, and Bratislava SAX. Exploration of exchange rates indicated that, in the long term, a large depreciation of the Czech koruna (CZK), Hungarian forint (HUF), and Polish zloty (PLN) was expected rather than a significant appreciation. The authors also show that there is a high correlation between reported cases and the depreciation of their exchange rates, implying that the ongoing pandemic has resulted in the depreciation of the Visegrad currencies. Furthermore, the result of the TGARCH model shows a significant negative link between the Visegrad stock market indices and the spread of COVID-19. The authors imply that the V4 countries are currently expected to be on the verge of the deepest recession they have experienced since their transition to market-oriented economies in the 1990s. Salamaga (2021) investigated FDI accumulation during the coronavirus crisis using correspondence analysis. The author finds that Hungary and the Czech Republic have experienced a great reduction in FDI accumulation compared to the other two countries. Lacka et al. (2020) investigated the trade and GDP of the V4 countries for the 1996-2018 period. The authors state that, in 2018, Slovakia was the weakest export economy in the V4. Moreover, in 2018, Germany was the main export and import country of the V4 countries. The author used a VEC model and Granger causality test and concluded that there is no long-term interdependence of the countries in the context of international trade and growth.

Astrov and Holzner (2021) presented comprehensive information on the effect of COVID-19 on the V4 countries. The Czech Republic has the largest number of cases and deaths per capita among the V4 countries, and Slovakia has the lowest. The authors investigate the EU transfers to the V4 countries and state that Poland has had the biggest transfer, followed by the Czech Republic, Hungary, and Slovakia. The volume of transfers was EUR 29.6bn, EUR 8.6bn, EUR 6.4bn, and EUR 6.3bn, respectively.

In a broader context, Hayakawa and Mukunoki (2021) investigated the impact of COVID-19 on global value chains using the export value of finished machinery products as a dependent variable to show the trade data and GDP of the investigated countries, and some dummy variables, such as regional trade agreement and COVID-19 dummies. Erokhin and Gao (2020) focused on the effect on food trade using the balance of food trade to measure trade. The authors use the number of confirmed COVID-19 cases to show the overall impact of the pandemic. Espitia et al. (2021) offered another paper that investigates the pandemic's effect, using a data period that starts from June 2020 as a beginning of the pandemic.

\section{Trade among V4 Countries}

International trade in the V4 consists of mutual import and export flows between the countries; however, it is strongly influenced by the dominant trading block-the EUwhich sets the rules and provides regulations for all countries. 
To compare the magnitude of trade flows: based on the Trademap data, the proportion of the imports of V4 countries in the total EU imports (exports)ranges between 1 and 3 per cent, and their total proportion in EU imports (exports) is about 6 per cent on average (see Figure 1).However, because of the global world trade decrease, in relative prices, during the COVID-19 period, both the numerator (the country trade) and the denominator (EU trade) decreased, and the change of their ratio is less than their absolute change. Thus, we cannot see the effect very well. Therefore, to see this effect clearly, working with absolute data will give better results.

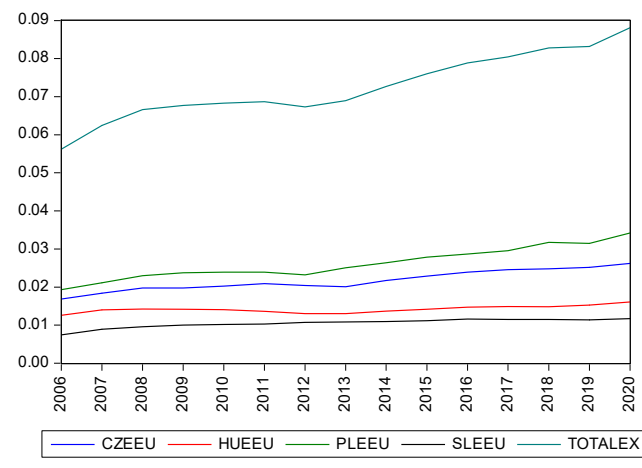

(a)

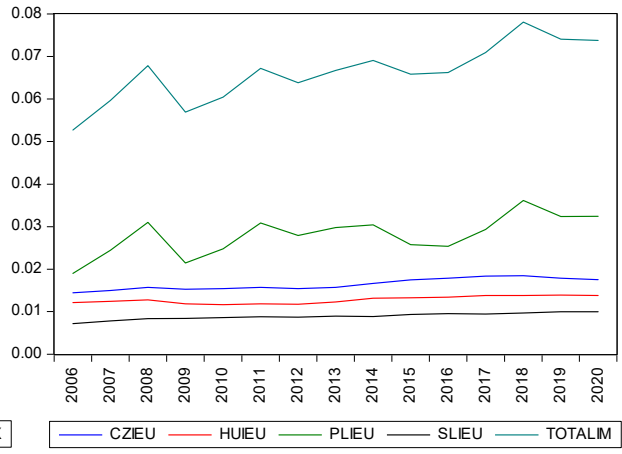

(b)

Figure 1. (a) Export Variables, (b) Import Variables. Trade ratio of V4 members. CZEEU: the Czech Republic's exports to Europe/Europe's exports to the world, HUEEU: Hungary's exports to Europe/Europe's exports to theworld, PLEEU: Poland's exports to Europe/Europe's exports to the world, SLEEU: Slovakia's exports to Europe/Europe's exports to the world, TOTALIM = CZEEU + HUEEU + PLEEU + LEEEU, CZIEU: the Czech Republic's imports from Europe/Europe's imports from the world, HUIEU: Hungary's imports from Europe/Europe's imports from the world, PLIEU: Poland's imports from Europe/Europe's imports from the world, SLIEU: Slovakia's imports from Europe/Europe's imports from the world, TOTALEX = CZIEEU + HUIEU + PLIEU + LEIEU.

To understand the trade flow among the V4 countries, we use the annual product trade data from the Trademap (trademap.org) website. Figure 2 shows the countries' bilateral trade with the other V4 countries and the sum of the three countries, which is named "tot". CfrHM is a Czech Republic import from Hungary, CfrPM is a Czech Republic import from Poland, and CfrSM is a Czech Republic import from Slovakia. In these graphs, the right-hand axis shows total data while the left-hand axis shows individual countries. The other variables are named with the same logic. Among the V4 countries, the main import partner of the Czech Republic is Poland, the second is Slovakia, and the third is Hungary. For Hungary, the other three partners' import value is slightly closer. For Slovakia and Poland, the Czech Republic is the main import partner, and the other two countries have very close values. For all the countries, we can see a decrease after 2019.

Figure 3 shows the countries' bilateral trade with other V4 countries. The sum of the three countries is abbreviated as "tot". CtoHX is a Czech export to Hungary, CtoPX is a Czech export to Poland, and CtoSX is a Czech export to Slovakia. The right-hand axis in these graphs shows the total data, and the left-hand axis shows individual countries. The other variables are named using the same logic. The Czech Republic's main export partner is Slovakia. Hungary has significantly lower values than the other three countries. For Hungary, the major export partner is Slovakia; for Poland and Slovakia, the major export partner is the Czech Republic. For Hungary, Poland, and Slovakia's export partners, the second and third partners have very close values. 


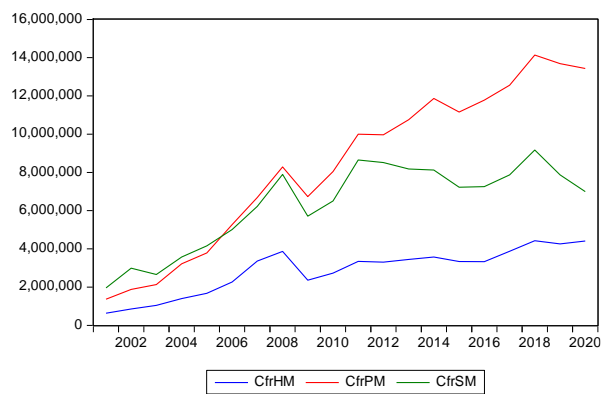

(a)

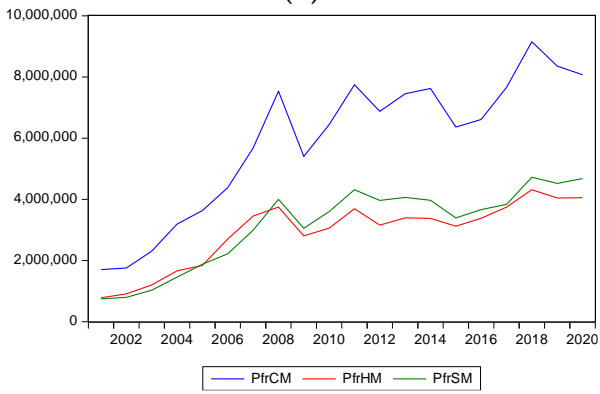

(c)

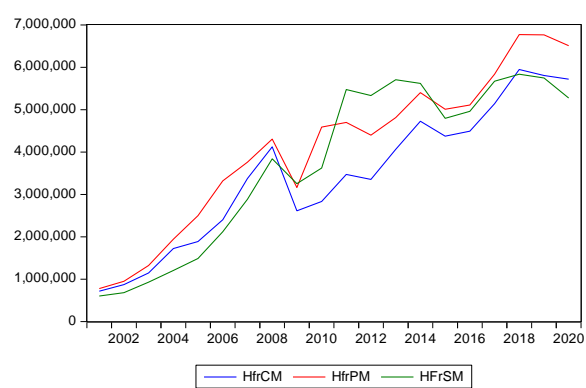

(b)

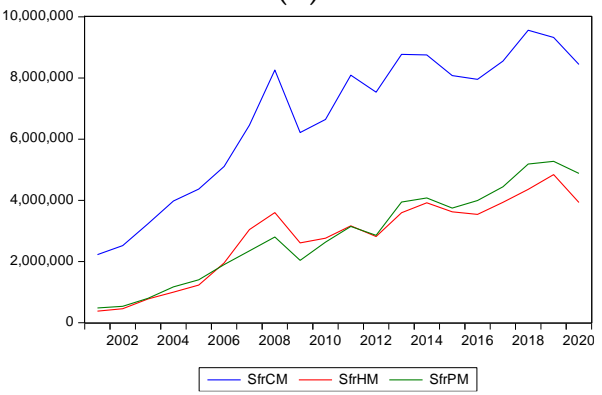

(d)

Figure 2. Imports of the countries from the other V4 members: (a) Czech Republic; (b) Hungary; (c) Poland; (d) Slovakia.

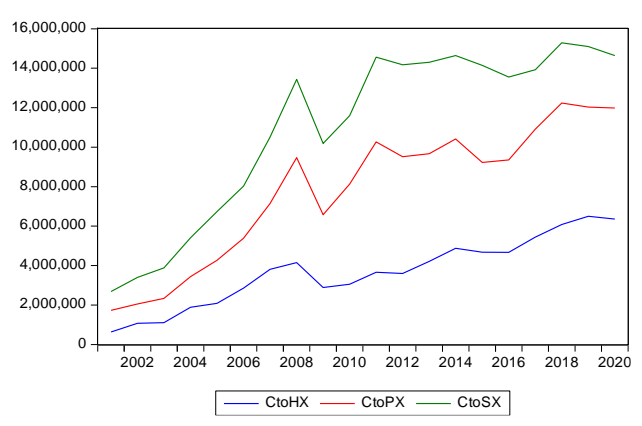

(a)

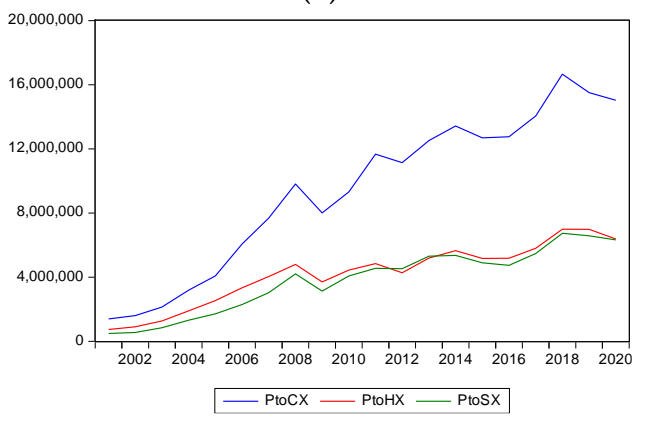

(c)

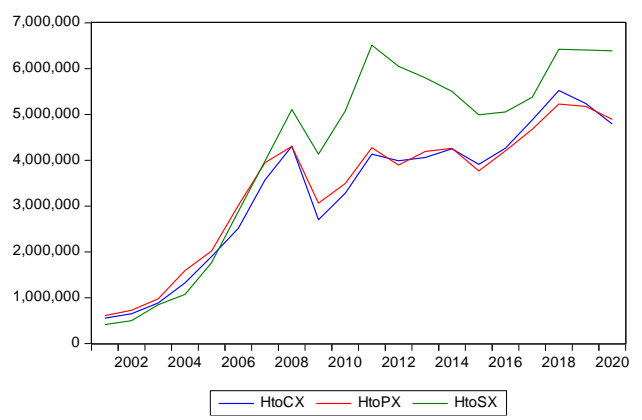

(b)

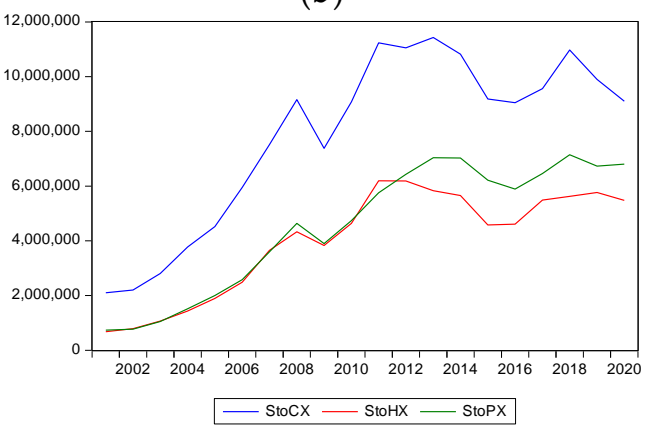

(d)

Figure 3. Exports of the countries from the other V4 members: (a) Czech Republic; (b) Hungary; (c) Poland; (d) Slovakia.

International trade in the V4 consists of mutual import and export flows between the countries; however, it is strongly influenced by the dominant trading block-the EUwhich sets the rules and provides regulations for all countries.

\section{Empirical Application (Data and Time Series)}

We use the monthly data for the 2010M1-2021M4 period. The trade and GDP data were collected from Eurostat (EU trade since 1988 by SITC [DS-018995] in euros), which 
provides the data based on the country reports. That is why the import value of country A from country B does not equal the export of country B to A. In the abbreviation of export and import data below, the first letter shows the reporter country, according to the Eurostat data presentation form, which categorizes bilateral trade countries as a reported country and a partner country. After collecting data country by country, the three partner countries' data were aggregated, and their abbreviation is labeled V4. Quarterly gross domestic product at market prices (current prices, millions of euros) was collected from Eurostat and then converted to monthly data using the EViews 10 linear interpolation method. To investigate the countries, we used the real broad effective exchange rate (Index $2010=100$ ) from FRED (Federal reserve economic data) as a proxy of the real exchange rate. Furthermore, because Slovakia's currency is the euro and the other three countries use their own currency, there will be no parity for Slovakia if we use the euro for the exchange rate. Because of this objective limitation, we selected the USD to use the same currency for all the countries.

Here, CV4M is Czech Republic's imports from the other three V4 countries. HV4M is Hungary's imports from the other three V4 countries, PV4M is Poland's imports from the other three V4 countries, and SV4M is Slovakia's imports from the other three V4 countries. GDPCZ is the gross domestic product of the Czech Republic. GDPHU is the gross domestic product of Hungary, GDPPL is the gross domestic product of Poland, GDPSL is the gross domestic product of Slovakia, and RBZC is the real exchange rate of the Czech Republic. RBHU is the real exchange rate of Hungary. RBPL is the real exchange rate of Poland. RBSK is the real exchange rate of Slovakia. CV4X is the Czech Republic's exports to the other three V4 countries. SV4X is Slovakia's exports to the other three V4 countries. HV4X is Hungary's exports to the other three V4 countries, and PV4X is Polish exports to the other three V4 countries.

At first, we seasonally adjusted all the series and added the "SA" abbreviation at the end of the other abbreviations. After seasonally adjusting the series, we made the logarithmic transformation except for the RER series. Although we took the logarithm after seasonal adjustment, we did not put "SA" at the end of the abbreviations because we did not want to use long abbreviations. ${ }^{2}$

In this paper, we aim to detect whether COVID-19 affects the trade model of the V4. The first shift, labeled D1, takes 1 from 2020:M04 to the end of the term and 0 otherwise, and the impulse dummy is named D2, and it takes 1 for 2020:M04 and 0 otherwise. D1 is the shift dummy, and D2istheimpulse dummy (Brüggemann and Lütkepohl 2006). The shift dummy shows structural change after the selected date. The impulse dummy shows a one-time effect on break time (Lutkepohl et al. 2004), i.e., how long the effect lasts. Our aim is to see if COVID-19 affects foreign trade only during the lockdown period or whether its effect persists after lockdowns. To determine the break date, we use two pieces of information; announcements of lockdown measures and graphical information. In the Czech Republic, a 30-day state of emergency was declared as of 12 March and was extended until 17 May 2020 (Vlada.cz 2021). In Slovakia, the lockdown lasted from 13 March until 14 May 2021, and subsequently, more moderate measures were applied (Policy Responses to COVID-19, International Monetary Fund (IMF) 2021). In Hungary, lockdown measures to moderate the pandemic began in mid-March (Ec.europa.eu 2021). In Poland, the Polish parliament introduced a statute on special measures on 2 March 2021 (Jaraczewski 2021), and so the starting month of the lockdown was March. We can see its effect in subsequent periods. Thus, we determine April as the break time supporting this idea with graphical information. Graphical information (Figure 4) shows a huge decrease in 2020:M04 in all export and import graphs. Previous research, such as that by Curto and Serrasqueiro (2021); Fu and Shen (2020); and Iyke (2020), use different outbreak dates for their dummy variables, but all use dummy 0 before the outbreak date and 1 after the outbreak to detect the effect of COVID-19. 


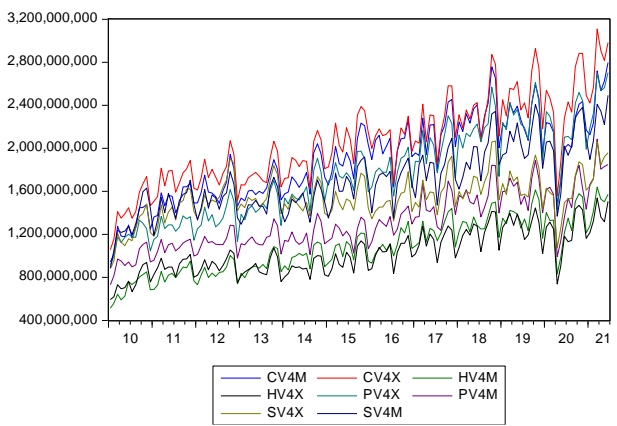

(a)

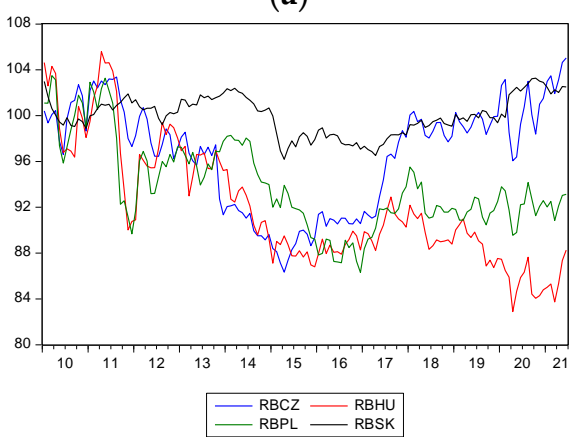

(c)

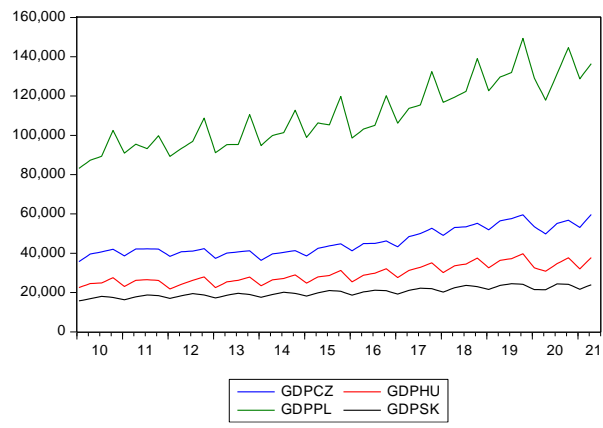

(b)

Figure 4. Development of imports, exports, GDP, and real exchange rates of the V4 countries from 2010 to 2021. (a) Imports and exports; (b) GDP; (c) real exchange rates.

\section{Methodology}

In international trade investigation, the gravity model is often used. The gravity model dates back to the 1960s, when Tinbergen (1962) used Newton's universal law of gravitation on international trade. In this model, the main variable is the distance between countries, similar to Newton's rule distance between particles. In short, it is "proportional to the gross national products of those countries and inversely proportional to the distance between them". In this research, we did not focus on the distance. In addition, for the gravity model, the researchers should use panel data. We estimate the relationship using time series data by using the ARDL bounds tests approach. This approach is new compared to the gravity model; it was developed by Pesaran and Pesaran (1997); Pesaran and Shin (1999); and Pesaran et al. (2001). A wide range of literature uses the ARDL model for trade, and is not only limited to the examples in Table 1 below, which shows some of the latest research.

Halicioglu (2008) investigates the J curve for Turkey and adopts his model from Rose and Yellen (1989). The author estimates the ARDL model for the relationship between the ratio of imports to exports, the real effective exchange rate and the industrial production index of industrial countries and Turkey. The author concludes that the industrial production index of industrial countries negatively affected trade while the industrial production index of Turkey positively affected trade, and the real exchange rate has no significant effect in the long run. The works by Bahmani-Oskooee and Malixi (1992); Rose (1990) are other papers that find that real exchange rates have no impact on the trade balance. Karam and Zaki (2015) show that both the trade in services and trade in goods is positively related to GDP in the MENA region by using initial GDP as a dependent variable, and real investment, population growth, secondary enrolment rate, arable land, trade in goods and trade in services as independent variables. Grimes (2006) examines the terms of trade and GDP relationship and finds that an increase in the terms of trade is associated with an increase in annual GDP. 
Table 1. Some models used in international trade research.

\begin{tabular}{|c|c|c|c|}
\hline Authors & Variables & Region & Method \\
\hline Mangir et al. (2017) & $\begin{array}{c}\text { Trade openness and economic } \\
\text { growth }\end{array}$ & Ten countries in Africa & Panel ARDL model \\
\hline Solarin and Shahbaz (2015) & $\begin{array}{l}\text { Economic growth and trade } \\
\text { openness }\end{array}$ & Malaysia & ARDL boundary approach \\
\hline $\begin{array}{c}\text { Bardi, Wajdi, and Mohammed Ali } \\
\text { Hfaiedh (2021) }\end{array}$ & GDP per capita, openness & $\begin{array}{l}\text { Eight countries } \\
\text { bordering the } \\
\text { Mediterranean }\end{array}$ & panel ARDL \\
\hline Kong et al. (2021) & $\begin{array}{c}\text { Foreign direct investment } \\
\text { (FDI } \mathrm{t}) \text {, trade openness (TOP t) } \\
\text { and real effective exchange } \\
\text { rate }\end{array}$ & China & ARDL model \\
\hline Halicioglu (2008) & $\begin{array}{l}\text { The trade balance; the real } \\
\text { effective exchange rate }\end{array}$ & Turkey & ARDL model \\
\hline Narayan and Smyth (2005) & $\begin{array}{l}\text { Trade liberalization and } \\
\text { economic growth }\end{array}$ & Fiji & ARDL model \\
\hline Farhani and Ozturk (2015) & $\begin{array}{l}\text { Trade openness has a positive } \\
\text { effect on } \mathrm{CO}_{2} \text { emissions }\end{array}$ & Tunisia & ARDL model \\
\hline Dogan and Turkekul (2016) & $\begin{array}{c}\text { Trade openness decreases } \mathrm{CO}_{2} \\
\text { emissions }\end{array}$ & USA & ARDL model \\
\hline Klasra (2011) & $\begin{array}{l}\text { Exports-led growth } \\
\text { hypothesis }\end{array}$ & Pakistan andTurkey & $\begin{array}{l}\text { ARDL approach to } \\
\text { cointegration }\end{array}$ \\
\hline
\end{tabular}

In our research, we set the export and import volumes of the countries as dependent variables, whilst the independent variables represent the host country's GDP, the partner country's GDP, and the real exchange rate index of the host country. Descriptive characteristics of used variables are in Appendix A. Before estimating the models, we first investigate the stationarity of the variables. Then we use the ADF test and PP test to analyze the timeseries features. Table 2 shows the unit root results. The results show that some series are $\mathrm{I}(0)$ while some are $\mathrm{I}(1)$. Based on the unit root results, we decided to use the autoregressive distributed lag (ARDL) method, since Johansen and Juselius (1990) cointegration test needs the same order integrated series, the ARDL bounds tests for cointegration developed by Pesaran, Shin, and Smith (see Pesaran and Pesaran 1997; Pesaran and Shin 1999; Pesaran et al. 2001) can be used no matter if the series are I(0), I(1), or both I(0) and I(1) (Saglam and Ugurlu 2013). 
Table 2. Unit root test results.

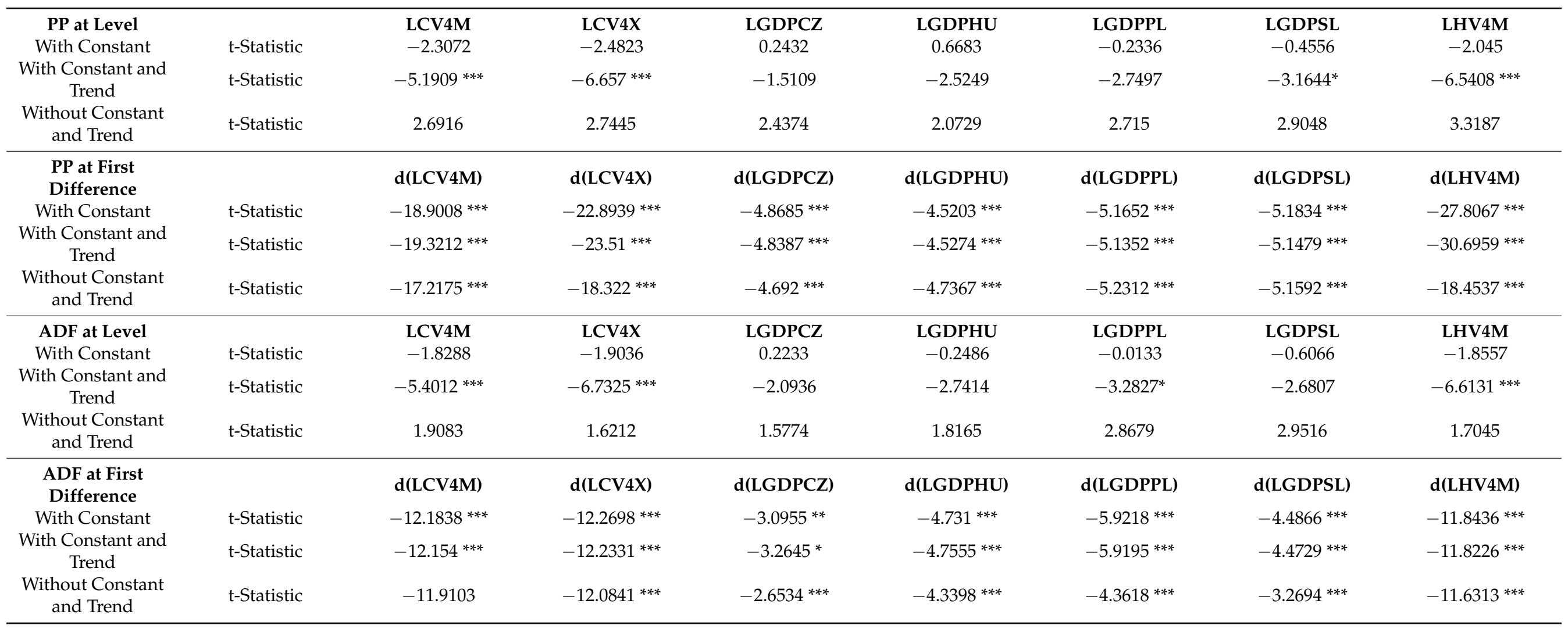


Table 2. Cont.

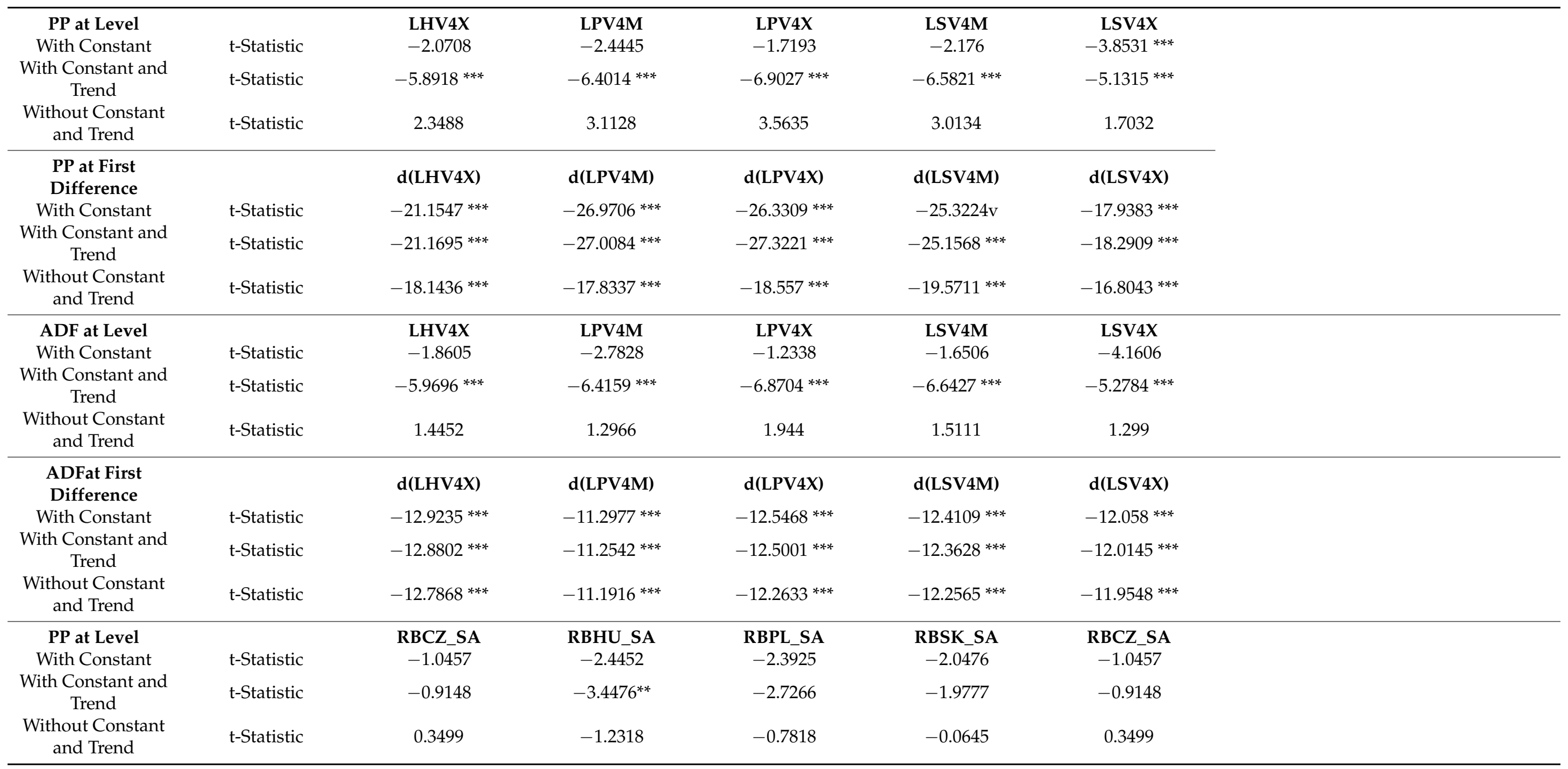


Table 2. Cont.

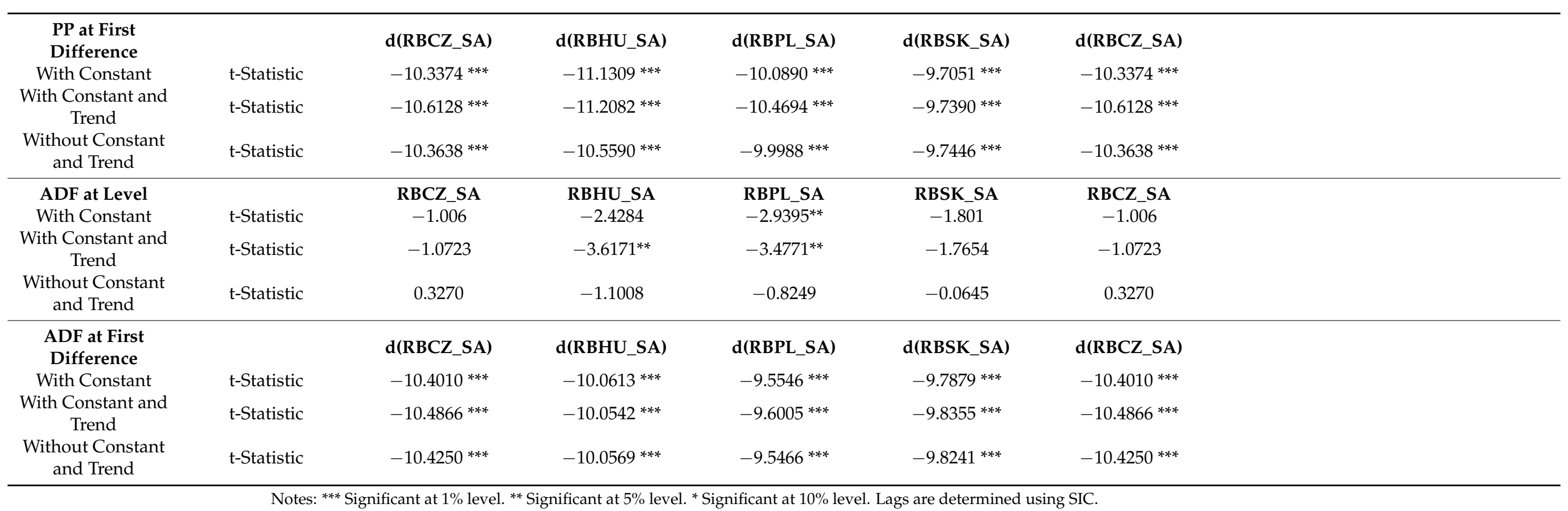


The used general model is represented below for import models. However, we did not write an equation for exports because, for exports, only the dependent variables will be changed to export.

$$
\begin{gathered}
\text { LCV4M }_{t}=\alpha_{0}+\alpha_{1} \text { LGDPCZ }_{t}+\alpha_{2} \text { LGDPHUZ }_{t}+\alpha_{3} \text { LGDPPL }_{t}+\alpha_{4} \text { LGDPSL }_{t}+\alpha_{5} \text { RBCZ_SA }_{t}+\varepsilon_{1 t} \\
\text { LHV4M }_{t}=\beta_{0}+\beta_{1} \text { LGDPCZ }_{t}+\beta_{2} \text { LGDPHUZ }_{t}+\beta_{3} \text { LGDPPL }_{t}+\beta_{4} \text { LGDPSL }_{t}+\beta_{5} \text { RBHU_SA }_{t}+\varepsilon_{2 t} \\
\text { LPV4M }_{t}=\delta_{0}+\delta_{1} \text { LGDPCZ }_{t}+\delta_{2} \text { LGDPHUZ }_{t}+\delta_{3} \text { LGDPPL }_{t}+\delta_{4} \text { LGDPSL }_{t}+\delta_{5} \text { RBPL_SA }_{t}+\varepsilon_{3 t} \\
\text { LSV4M }_{t}=\theta_{0}+\theta_{1} \text { LGDPCZ }_{t}+\theta_{2} \text { LGDPHUZ }_{t}+\theta_{3} \text { LGDPPL }_{t}+\theta_{4} \text { LGDPSL }_{t}+\theta_{5} \text { RBSL_SA }_{t}+\varepsilon_{4 t}
\end{gathered}
$$

where $\alpha_{i}, \beta_{\mathrm{i}}, \delta_{\mathrm{i}}$ and $\theta_{\mathrm{i}}$ are the coefficients, and $\varepsilon_{i t}$ terms are the disturbance terms (Fuinhas and Marques 2012). We add the dummy variables in the ARDL model because it allows using a fixed regressor. The ARDL bounds test equations, in which we test the significance of the COVID-19 dummy variable of these models, are as follows.

$$
\begin{aligned}
\Delta \mathrm{LCV}_{4}=\varnothing_{0} & +\sum_{i=1}^{i} \varnothing_{1 i} \Delta \mathrm{LCV}_{t} \mathrm{M}_{\mathrm{t}-i}+\sum_{i=1}^{k} \varnothing_{2 i} \Delta \mathrm{LGDPCZ}_{\mathrm{t}-i}+\sum_{i=1}^{l} \varnothing_{3 i} \Delta \mathrm{LGDPHU}_{\mathrm{t}-i}+\sum_{i=1}^{n} \varnothing_{4 i} \Delta \mathrm{LGDPPL}_{\mathrm{t}-i} \\
& +\sum_{i=1}^{o} \varnothing_{5 i} \Delta \mathrm{LGDPSL}_{\mathrm{t}-i}+\sum_{i=1}^{p} \varnothing_{6 i} \Delta \mathrm{RBCZ}_{\mathrm{SAt}-i}+\varnothing_{7} \mathrm{LCT}_{\mathrm{t}-1}+\varnothing_{8} \mathrm{LGDPCZ}_{\mathrm{t}-1}+\varnothing_{9} \mathrm{LGDPHUZ}_{\mathrm{t}-1} \\
& +\varnothing_{10} \mathrm{LGDPPL}_{\mathrm{t}-1}+\varnothing_{11} \mathrm{LGDPSK}_{\mathrm{t}-1}+\varnothing_{12} \mathrm{RBCZ}_{-} \mathrm{SA}_{\mathrm{t}-1}+\varnothing_{13} D_{1}+\varnothing_{14} D_{2}+\omega_{1 t}
\end{aligned}
$$

$$
\begin{aligned}
\Delta \text { LHV}_{4}=\varphi_{0} & +\sum_{i=1}^{i} \varphi_{1 i} \Delta \text { LHV4M }_{\mathrm{t}-\mathrm{i}}+\sum_{i=1}^{k} \varphi_{2 i} \Delta \mathrm{LGDPCZ}_{\mathrm{t}-\mathrm{i}}+\sum_{i=1}^{l} \varphi_{3 i} \Delta \mathrm{LGDPHU}_{\mathrm{t}-\mathrm{i}}+\sum_{i=1}^{n} \varphi_{4 i} \Delta \mathrm{LGDPPL}_{\mathrm{t}-i} \\
& +\sum_{i=1}^{o} \varphi_{5 i} \Delta \mathrm{LGDPSK}_{\mathrm{t}-i}+\sum_{i=1}^{p} \varphi_{6 i} \Delta \mathrm{RBHU}_{\mathrm{SA}-i}+\varphi_{7} \mathrm{LHT}_{\mathrm{t}-1}+\varphi_{8} \mathrm{LGDPCZ}_{\mathrm{t}-1}+\varphi_{9} \mathrm{LGDPHUZ}_{\mathrm{t}-1} \\
& +\varphi_{10} \mathrm{LGDPPL}_{\mathrm{t}-1}+\varphi_{11} \mathrm{LGDPSK}_{\mathrm{t}-1}+\varphi_{12} \text { RBHU_SA }_{\mathrm{t}-1}+\varphi_{13} D_{1}+\varphi_{14} D_{2}+\omega_{2 t}
\end{aligned}
$$

$$
\begin{aligned}
\Delta \text { LPV4M }_{t}=\gamma_{0} & +\sum_{i=1}^{i} \gamma_{1 i} \Delta \text { LPV4M }_{\mathrm{t}-\mathrm{i}}+\sum_{i=1}^{k} \gamma_{2 i} \Delta \mathrm{LGDPCZ}_{\mathrm{t}-i}+\sum_{i=1}^{l} \gamma_{3 i} \Delta \mathrm{LGDPHU}_{\mathrm{t}-i}+\sum_{i=1}^{n} \gamma_{4 i} \Delta \mathrm{LGDPPL}_{\mathrm{t}-i} \\
& +\sum_{i=1}^{o} \gamma_{5 i} \Delta \mathrm{LGDPSK}_{\mathrm{t}-i}+\sum_{i=1}^{p} \gamma_{6 i} \Delta \mathrm{RBPL}_{\mathrm{SAt}-i}+\gamma_{7} \mathrm{LPT}_{\mathrm{t}-1}+\gamma_{8} \mathrm{LGDPCZ}_{\mathrm{t}-1}+\gamma_{9} \mathrm{LGDPHUZ}_{\mathrm{t}-1} \\
& +\gamma_{10} \mathrm{LGDPPL}_{\mathrm{t}-1}+\gamma_{11} \text { LGDPSK }_{\mathrm{t}-1}+\gamma_{12} \text { RBPL_SA }_{\mathrm{t}-1}+\gamma_{13} D_{1}+\gamma_{14} D_{2}+\omega_{3 t}
\end{aligned}
$$

$$
\begin{aligned}
\Delta \text { LS4VM }_{t}=\lambda_{0} & +\sum_{i=1}^{i} \lambda_{1 i} \Delta \text { LS4VM }_{\mathrm{t}-\mathrm{i}}+\sum_{i=1}^{k} \lambda_{2 i} \Delta \mathrm{LGDPCZ}_{\mathrm{t}-\mathrm{i}}+\sum_{i=1}^{l} \lambda_{3 \mathrm{i}} \Delta \mathrm{LGDPHU}_{\mathrm{t}-\mathrm{i}}+\sum_{i=1}^{n} \lambda_{4 \mathrm{i}} \Delta \mathrm{LGDPPL}_{\mathrm{t}-\mathrm{i}} \\
& +\sum_{i=1}^{o} \lambda_{5 \mathrm{i}} \Delta \mathrm{LGDPSL}_{\mathrm{t}-\mathrm{i}}+\sum_{i=1}^{p} \lambda_{6 \mathrm{i}} \Delta \text { RBPLSAt }-\mathrm{i}+\lambda_{7} \mathrm{LST}_{\mathrm{t}-1}+\lambda_{8} \mathrm{LGDPCZ}_{\mathrm{t}-1}+\lambda_{9} \mathrm{LGDPHUZ}_{\mathrm{t}-1} \\
& +\lambda_{10} \mathrm{LGDPPL}_{\mathrm{t}-1}+\lambda_{11} \mathrm{LGDPSL}_{\mathrm{t}-1}+\lambda_{12} \text { RBPLSA }_{t-1}+\lambda_{13} D_{1}+\lambda_{14} D_{2}+\omega_{4 t}
\end{aligned}
$$

The lagged variable coefficient shows long-run dynamics, and, except for the lagged values of the dependent variable, the coefficient of all the lagged level variables shows short-run dynamics. The expected sign of the lagged dependent variable is less than zero $\left(\varnothing_{7}<0, \varphi_{7}<0, \gamma_{7}<0, \lambda_{7}<0\right)$.

\section{Results}

In the first step of the ARDL bound approach, we test the presence of long-run relationships in the models by using the bounds test. The null hypothesis of the bounds test is that there is no cointegration amongst the variables for each model (Fuinhas and Marques 2012). If we reject the null hypothesis and find that there is cointegration among the variables, the second step is to estimate the conditional error correction regression. In this error correction model (ECM), we can see the short-run relationship, and in these models, the error correction term $\mathrm{EC}_{\mathrm{t}-1}$ should be significant and should have a negative 
sign. A negative and significant $\mathrm{EC}_{\mathrm{t}-1}$ shows the existence of the speed of adjustment from short-run disequilibrium towards the state of long-run equilibrium.

At first, we test the long-run relationship for the imports of each V4 country then estimate the error correction model to see whether the dummy variables are significant or not. Table 2 shows the bounds test results of the import models. The empirical results indicate that there is a long-run relationship of at least a 1 percent level of significance (Table 3).

Table 3. F-statistics for cointegration relationship for import models.

\begin{tabular}{ccccc}
\hline & Czech Republic & Hungary & Poland & Slovakia \\
\hline F-statistics & $3.160^{* *}$ & $3.5028^{*}$ & $4.0895^{* *}$ & $6.6367^{* * *}$ \\
\hline Notes: ${ }^{* * *}$ Significant at $1 \%$, level. ${ }^{* *}$ Significant at $5 \%$ level. ${ }^{*}$ Significant at $10 \%$ level. Source: own research.
\end{tabular}

Table 3 shows that, for Slovakia, this result is significant at a 5\% level. However, we do not interpret the long-run models because this paper aims to test the COVID-19 effect. Table 4 shows the ARDL model results for imports of V4 countries. In the models, the impulse dummy variables (D2) areat a 1\% significance level. Therefore, we prove our expectations that the COVID-19 effect exists after the lockdown. Because the impulse dummy is significant, it can be determined that lockdown has no effect during the following periods of lockdown on imports; it affects only the lockdown month. Diagnostic tests show that we have no violation of assumptions (such as autocorrelation, specification) of the model in Poland. In the Czech Republic, there are weak (at the 10\% level) second order and third order autocorrelations based on the BG test. However, we detect a strong autocorrelation ( $1 \%$ level) and specification error for the Hungary model based on the Ramsey RESET test. We determined lags based on SIC for all the models. For Hungary, based on SIC, the model was ARDL $(1,0,0,0,0,0)$ and to overcome misspecification and the autocorrelation problem, first, we increased lags, and the last model is $\operatorname{ARDL}(3,3,0,2,4,0)$, but still, the autocorrelation existed. For eliminating the autocorrelation, we use NeweyWest HAC standard errors. This option provides heteroscedasticity and autocorrelation consistent covariance (HAC) estimators. We use the Newey and West (1987) technique from several techniques (Heberle and Sattarhoff 2017) to estimate HAC.

We know that if any model has autocorrelation, the coefficients will be unbiased and consistent; the problem is their variances; thus, coefficients are inefficient (Gujarati and Porter 2009). That is why this correction will affect the standard errors of the coefficients, and we will see the effect on significance. After the estimation, we saw that the D2 dummy is still significant (Appendix B).

Table 4 shows the short-run results of the import models. The import model results show that the real exchange rate is not significant in all the countries. For the GDP variables, we have different results for the short-run models. In all countries, their own GDP is significant in all differenced one lagged GDP variables; for the partner countries GDP, we have different results. Except for Slovakia, all models are stable; there are no structural breaks. For all models, CUSUM and CUSUM SQ tests show that the models are stable. The CUSUM tests provide a diagnostic tool for detecting unknown structural breaks (Dao 2021) and show the coefficients' stability. After eliminating the D1 dummy variable from Slovakia's import model, we have a stable model with a significant D2 dummy (Appendix C).

Finally, we have significant D2 variables in all models, which have a long-run relationship and significant error correction term. Dummy variable D2 is significant and negative in all models, and D1 is insignificant. This result implies that the effect of COVID-19 has no impact after lockdown; it has a one-time effect on imports. Subsequently, the effect is decreasing. 
Table 4. ARDL model results for imports.

\begin{tabular}{|c|c|c|c|c|c|c|c|}
\hline \multicolumn{2}{|c|}{$\begin{array}{c}\text { Czech Republic } \\
\text { ARDL }(3,2,0,0,0,0)\end{array}$} & \multicolumn{2}{|c|}{ Hungary ARDL(3,3,0,2,4,0) } & \multicolumn{2}{|c|}{ Poland ARDL $(3,0,1,2,0,2)$} & \multicolumn{2}{|c|}{ Slovakia ARDL $(3,0,2,0,0,0)$} \\
\hline Variable & Coefficient & Variable & Coefficient & Variable & Coefficient & Variable & Coefficient \\
\hline Constant & 1.5248 * & Constant & 1.9256 & Constant & $4.0374^{* * *}$ & Constant & $4.3579 * * *$ \\
\hline $\mathrm{ECT}_{\mathrm{t}-1}$ & $-0.2405^{* * *}$ & $\mathrm{ECT}_{\mathrm{t}-1}$ & $-0.4725^{* * *}$ & $\mathrm{ECT}_{\mathrm{t}-1}$ & $-0.4715^{* * *}$ & $\mathrm{ECT}_{\mathrm{t}-1}$ & $-0.5517 * * *$ \\
\hline $\mathrm{LGDPCZ}_{\mathrm{t}-1}$ & 0.0426 & LGDPCZ & -0.3170 & $\mathrm{LGDPCZ}_{\mathrm{t}-1}$ & 0.1889 & $\mathrm{LGDPCZ}_{\mathrm{t}-1}$ & $0.4925^{* * *}$ \\
\hline LGDPHU & -0.2124 & LGDPHU & 0.2739 & LGDPHU $_{\mathrm{t}-1}$ & -0.0761 & $\mathrm{LGDHU}_{\mathrm{t}-1}$ & -0.4686 \\
\hline LGDPPL & 0.2734 & LGDPPL & 0.1259 & LGDPPL $_{t-1}$ & 0.4057 & LGDPPL & 0.1085 \\
\hline LGDPSL & 0.2261 & LGDPSL & 0.7194 & LGDPSL & 0.0168 & LGDPSL & $0.6005^{* *}$ \\
\hline RBCZ_SA & -0.0008 & RBHU_SA & -0.0012 & RBPL_SA & -0.0028 & RBSK_SA & -0.0031 \\
\hline$\Delta \mathrm{LCV} 4 \mathrm{M}_{\mathrm{t}-1}$ & $-0.5923^{* * *}$ & $\Delta \mathrm{LHV} \mathrm{M}_{\mathrm{t}-1}$ & $-0.4232^{* * *}$ & $\Delta \mathrm{LPV} 4 \mathrm{M}_{\mathrm{t}-1}$ & $-0.2635^{* * *}$ & $\Delta \mathrm{LSV}_{4} \mathrm{M}_{\mathrm{t}-1}$ & $-0.3547^{* * *}$ \\
\hline$\Delta \mathrm{LCV} 4 \mathrm{M}_{\mathrm{t}-2}$ & $-0.3410^{* * *}$ & $\Delta \mathrm{LHV} \mathrm{M}_{\mathrm{t}-2}$ & $-0.3295^{* * *}$ & $\Delta \mathrm{LCV} 4 \mathrm{M}_{\mathrm{t}-2}$ & $-0.1253 *$ & $\Delta \mathrm{LSV}_{4} \mathrm{M}_{\mathrm{t}-2}$ & $-0.2461^{* * *}$ \\
\hline$\triangle \mathrm{LGDPCZ}$ & -0.8670 & $\triangle \mathrm{LGDPCZ}$ & -1.0658 & $\triangle \mathrm{LGDPHU}$ & 0.9188 & $\triangle \mathrm{LGDPHU}$ & $-1.7665^{* * *}$ \\
\hline$\Delta \mathrm{LGDPCZ}_{\mathrm{t}-1}$ & $3.4081^{* * *}$ & $\triangle \mathrm{LGDPCZ}_{\mathrm{t}-1}$ & -0.4345 & $\triangle \mathrm{LGDPPL}$ & -1.0706 & $\Delta \mathrm{LGDPHU}_{\mathrm{t}-1}$ & $2.6667 * * *$ \\
\hline D1 & 0.0088 & $\triangle \mathrm{LGDPCZ}_{\mathrm{t}-2}$ & $2.7375^{* * *}$ & $\Delta \mathrm{LGDPPL}_{\mathrm{t}-1}$ & $1.8200^{* * *}$ & D1 & 0.0257 \\
\hline \multirow[t]{8}{*}{ D2 } & $-0.3024^{* * *}$ & $\triangle \mathrm{LGDPPL}$ & -0.7342 & $\triangle$ RBPL_SA & $-0.0075^{*}$ & D2 & $-0.3139 * * *$ \\
\hline & & $\Delta \mathrm{LGDPPL}_{\mathrm{t}-1}$ & $1.7751^{* * *}$ & $\Delta \mathrm{RBPL} \_\mathrm{SA}_{\mathrm{t}-1}$ & $0.0085^{* *}$ & & \\
\hline & & $\triangle$ LGDPSL & 0.8120 & $\mathrm{D} 1$ & 0.0115 & & \\
\hline & & $\Delta$ LGDPSL $_{\mathrm{t}-1}$ & $1.9222 *$ & D2 & $-0.3979 * * *$ & & \\
\hline & & $\Delta$ LGDPSL $_{t-2}$ & -1.3937 & & & & \\
\hline & & $\Delta$ LGDPSL $_{\mathrm{t}-3}$ & $-1.6585^{* *}$ & & & & \\
\hline & & D1 & 0.0184 & & & & \\
\hline & & D2 & $-0.3640^{* * *}$ & & & & \\
\hline \multicolumn{8}{|c|}{ Diagnostic tests } \\
\hline BG-LM(2) & $5.2656^{*}$ & \multicolumn{2}{|c|}{$9.3736^{* * *}$} & \multicolumn{2}{|c|}{4.4554} & \multicolumn{2}{|c|}{5.9992} \\
\hline BG-LM(3) & 5.2664 & \multicolumn{2}{|c|}{$9.4844^{* *}$} & \multicolumn{2}{|c|}{6.0104} & \multicolumn{2}{|c|}{6.0104} \\
\hline BG-LM(4) & $8.0073 *$ & \multicolumn{2}{|c|}{$9.4973^{* *}$} & \multicolumn{2}{|c|}{6.8832} & \multicolumn{2}{|c|}{6.8832} \\
\hline RESET(1) & 1.4762 & \multicolumn{2}{|c|}{0.3552} & \multicolumn{2}{|c|}{0.7126} & \multicolumn{2}{|c|}{0.7126} \\
\hline CUSUM(SQ) & $S(S)$ & \multicolumn{2}{|c|}{$S(S)$} & \multicolumn{2}{|c|}{$\mathrm{S}(\mathrm{S})$} & \multicolumn{2}{|c|}{ US(US) } \\
\hline
\end{tabular}

Notes $* * *$, and ${ }^{* * *}$ denote significance at $10 \%, 5 \%$, and $1 \%$, respectively. BG-LM presents the Breusch-Godfrey LM test, which has a null hypothesis that the equations have no serial correlation. RESET presents the Ramsey RESET test, and the null hypothesis is that there is no misspecification in functional form. Lags are determined using SIC. Source: own research.

Table 5 shows the bounds test results for the export models. We rejected the null hypothesis of cointegration at a $1 \%$ level in all countries.

Table 5. F-statistics for cointegration relationship for export models.

\begin{tabular}{ccccc}
\hline & Czech Republic & Hungary & Poland & Slovakia \\
\hline F-statistics & $4.726^{* * *}$ & $5.9886^{* * *}$ & $6.6890^{* * *}$ & $4.4655^{* *}$ \\
\hline Notes $^{* * *}$ Significant at $\%^{*}$, level $^{* *}$ Significant & $5^{*}$ level Source: & Swn research
\end{tabular}

Notes: ${ }^{* *}$ Significant at $1 \%$, level. ${ }^{* *}$ Significant at $5 \%$ level. Source: own research.

Table 6 shows the results of the ARDL models for exports. The export model results show that the real exchange rate is not significant except in Poland. For the GDP variables, we have different results for the short-run models. In all countries, their own GDP is significant in all differenced lagged GDP variables; for the partner countries' GDP, we have different results. Similar to the import models, impulse dummy variables are significant for the export models. We had an autocorrelation based on SIC for the Czech Republic; we increased the lag length, then the model is $\operatorname{ARDL}(3,4,2,0,1,0)$. Without autocorrelation, it was ARDL $(3,4,0,0,0,0)$. The Hungary model is not stable, and we could not overcome this problem. It shows that we may need more dummy variables or some other variables to explain the exports of Hungary. Finally, we estimate the model with Newey-West HAC standard errors, and we have a significant D2 variable again (Appendix D). 
Table 6. ARDL model results for exports.

\begin{tabular}{|c|c|c|c|c|c|c|c|}
\hline \multicolumn{2}{|c|}{$\begin{array}{c}\text { Czech Republic } \\
\text { ARDL }(3,4,2,0,1,0)\end{array}$} & \multicolumn{2}{|c|}{ Hungary ARDL $(3,0,2,0,0,0)$} & \multicolumn{2}{|c|}{ Poland ARDL $(3,2,0,0,0,0)$} & \multicolumn{2}{|c|}{ Slovakia ARDL $(3,0,2,0,0,0)$} \\
\hline Variable & Coefficient & Variable & Coefficient & Variable & Coefficient & Variable & Coefficient \\
\hline Constant & $2.8234^{* * *}$ & Constant & $3.0609 * *$ & Constant & $2.8735^{* * *}$ & Constant & $2.9652 * * *$ \\
\hline $\mathrm{ECT}_{\mathrm{t}-1}$ & $-0.4280^{* * *}$ & $\mathrm{ECT}_{\mathrm{t}-1}$ & $-0.4739^{* * *}$ & $\mathrm{ECT}_{\mathrm{t}-1}$ & $-0.6062^{* * *}$ & $\mathrm{ECT}_{\mathrm{t}-1}$ & $-0.2313^{* * *}$ \\
\hline $\mathrm{LGDPCZ}_{\mathrm{t}-1}$ & 0.1950 & LGDPCZ & $0.5183^{* * *}$ & $\mathrm{LGDPCZ}_{\mathrm{t}-1}$ & $-0.5756^{* * *}$ & LGDPCZ & $0.3664^{* *}$ \\
\hline $\mathrm{LGDPHU}_{\mathrm{t}-1}$ & -0.4254 & $\mathrm{LGDPHU}_{\mathrm{t}-1}$ & -0.2096 & LGDPHU & 0.4119 & $\mathrm{LGDHU}_{\mathrm{t}-1}$ & $-0.7314^{* *}$ \\
\hline LGDPPL & 0.4368 & LGDPPL & -0.1560 & LGDPPL & $0.7322 * *$ & LGDPPL & 0.5399 * \\
\hline LGDPSL $_{t-1}$ & 0.3713 & LGDPSL & 0.5260 & LGDPSL & 0.3960 & LGDPSL & -0.0558 \\
\hline RBCZ_SA & -0.0012 & RBHU_SA & -0.0004 & RBCZ_PL & $-0.0049^{* * *}$ & RBSL_SA & -0.0019 \\
\hline$\Delta \mathrm{LCV} 4 \bar{X}_{\mathrm{t}-1}$ & $-0.5908^{* * *}$ & $\Delta \operatorname{LHV}_{4} \bar{X}_{\mathrm{t}-1}$ & $-0.3254^{* * *}$ & $\Delta \mathrm{LCV} 4 \bar{X}_{\mathrm{t}-1}$ & $-0.3389^{* * *}$ & $\Delta \mathrm{LSV} 4 \mathrm{X}_{\mathrm{t}-1}$ & $-0.4797^{* * *}$ \\
\hline$\Delta \mathrm{LCV}_{4} \mathrm{X}_{\mathrm{t}-2}$ & $-0.4624^{* * *}$ & $\Delta \mathrm{LHV}_{4} \mathrm{X}_{\mathrm{t}-2}$ & $-0.2645^{* * *}$ & $\Delta \mathrm{LCV} 4 \mathrm{X}_{\mathrm{t}-2}$ & $-0.2354^{* * *}$ & $\Delta \mathrm{LSV}_{4} \mathrm{X}_{\mathrm{t}-2}$ & $-0.3089^{* * *}$ \\
\hline$\triangle \mathrm{LGDPCZ}$ & -0.1192 & $\triangle \mathrm{LGDPHU}$ & $-1.1560 * *$ & $\triangle \mathrm{LGDPCZ}$ & $-2.0046^{* * *}$ & $\triangle \mathrm{LGDPHU}$ & $-1.1024^{* *}$ \\
\hline$\Delta \mathrm{LGDPCZ}_{\mathrm{t}-1}$ & $2.1681^{* *}$ & $\Delta \mathrm{LGDPHU}_{\mathrm{t}-1}$ & $2.3805^{* * *}$ & $\Delta \mathrm{LGDPCZ}_{\mathrm{t}-1}$ & $2.8100^{* * *}$ & $\Delta \mathrm{LGDPHU}_{\mathrm{t}-1}$ & $2.0860^{* * *}$ \\
\hline$\triangle \mathrm{LGDPCZ}_{\mathrm{t}-2}$ & $2.6105^{* * *}$ & D1 & 0.0084 & D1 & 0.0076 & D1 & 0.0129 \\
\hline$\triangle \mathrm{LGDPCZ}_{\mathrm{t}-3}$ & $-1.5675^{* *}$ & D2 & $-0.4117^{* * *}$ & D2 & $-0.3406^{* * *}$ & D2 & $-0.3296^{* * *}$ \\
\hline$\triangle \mathrm{LGDPHU}$ & -0.9302 & & & & & & \\
\hline$\Delta \mathrm{LGDPHU}_{\mathrm{t}-1}$ & $1.4248^{* *}$ & & & & & & \\
\hline$\triangle \mathrm{LGDPSL}$ & -1.2209 & & & & & & \\
\hline D1 & 0.0247 & & & & & & \\
\hline D2 & $-0.3054^{* * *}$ & & & & & & \\
\hline \multicolumn{8}{|c|}{ Diagnostic tests } \\
\hline BG-LM(2) & $5.1228 *$ & \multicolumn{2}{|c|}{$6.9519 * *$} & \multicolumn{2}{|c|}{3.9673} & \multicolumn{2}{|c|}{$7.3711^{* *}$} \\
\hline BG-LM(3) & 5.6496 & \multicolumn{2}{|c|}{$7.0451 *$} & \multicolumn{2}{|c|}{4.0931} & \multicolumn{2}{|c|}{7.4114 * } \\
\hline BG-LM(4) & 7.2814 & \multicolumn{2}{|c|}{$9.8550 * *$} & \multicolumn{2}{|c|}{4.4201} & \multicolumn{2}{|c|}{$9.1806^{*}$} \\
\hline RESET(1) & 0.7200 & \multicolumn{2}{|c|}{1.9886} & \multicolumn{2}{|c|}{1.2972} & \multicolumn{2}{|c|}{0.0233} \\
\hline CUSUM(SQ) & $S(S)$ & \multicolumn{2}{|c|}{ US(US) } & \multicolumn{2}{|c|}{$S(S)$} & \multicolumn{2}{|c|}{$S(S)$} \\
\hline
\end{tabular}

$*, * *$, and ${ }^{* * *}$ denote significance at $10 \%, 5 \%$, and $1 \%$, respectively. BG-LM presents the Breusch-Godfrey LM test, which has a null hypothesis that the equations have no serial correlation. RESET presents the Ramsey RESET test, and the results confirm that there is no misspecification in functional form. Lags are determined using SIC. Source: own research.

\section{Conclusions and Discussion}

The impact of COVID-19 was damaging on all economies, whether developed, less developed or transitioning, as in the case of the V4 countries. The global effect can be detected in the development of major macroeconomic indicators, as well as health and social indicators, around the world (e.g., Vidya and Prabheesh 2020; Anand et al. 2020; Barbero et al. 2021; Jindřichovská and Uğurlu 2021).

Using the ARDL model, we attempted to detect whether and how COVID-19 affects trade among the Visegrad Four. After a thorough exploration of the time series of major trade variables (imports, exports, GDP, and real exchange rates), we decided to use the ARDL bounds test approach, which does not insist on variables being in the same degree of integration and having the same lag.

The analysis has concentrated chiefly on the short-term effect of COVID-19, and the results have disclosed that there was a structural change in international trade. We found that real exchange rates have no impact on trade in all the countries, similar to the results of (Bahmani-Oskooee and Malixi 1992; Rose 1990). The results of our models indicate that, among the V4, COVID-19 has a significant effect on the international trade in all the Visegrad countries. We have also observed a long-term cointegration relation in all countries, but, in this paper, we principally evaluate the short-term effect caused by the COVID-19 pandemic.

As a limitation of this study, we can point out that we have concentrated only on mutual trade between the Visegrad Four, and we have ignored the rest of the world, which may have a significant impact. Moreover, when exploring the previous studies and current statistical reports, we can see that there were significant linkages to some other neighboring 
countries, e.g., Germany and Austria. The most significant trade links are between the V4 countries and Germany. Furthermore, Germany is undoubtedly the engine of the European economy, and its exports and imports are important for all European countries. Therefore, we suggest that the link between the V4 and Germany needs to be explored in the next development of this study.

Author Contributions: Conceptualization, I.J. and E.U.; methodology, E.U.; validation, I.J. and E.U.; formal analysis, I.J. and E.U.; investigation, E.U.; resources, E.U.; data curation, E.U.; writingoriginal draft preparation, I.J. and E.U.; writing—review and editing, I.J. and E.U.; visualization, E.U.; supervision, I.J.; project administration, I.J.; funding acquisition, I.J. All authors have read and agreed to the published version of the manuscript.

Funding: This research received no external funding. The APC was funded by Metropolitan University Prague grant from the Institutional Fund for the Long-term Strategic Development of Research Organization.

Institutional Review Board Statement: Not applicable.

Informed Consent Statement: Not applicable.

Data Availability Statement: Not applicable.

Acknowledgments: This paper is the result of the Metropolitan University Prague research project no. 93-02 "International Business, Financial Management and Tourism" (2022) based on a grant from the Institutional fund for the Long-term Strategic Development of Research Organizations.The authors would also like to express their thanks to anonymous reviewers of the paper and to academic editors of the journal for their guidance and helpful comment.

Conflicts of Interest: The authors declare no conflict of interest.

\section{Appendix A}

Table A1. Descriptive Statistics of used variables.

\begin{tabular}{|c|c|c|c|c|c|c|c|c|c|c|c|c|}
\hline & CV4M & CV4X & GDPCZ & GDPHU & GDPPL & GDPSK & HV4M & HV4X & PV4M & PV4X & SV4X & SV4M \\
\hline Mean & $\begin{array}{c}1.89 \times \\
10^{9}\end{array}$ & $\begin{array}{c}2.05 \times \\
10^{9}\end{array}$ & 45821.09 & 29398.86 & 110351.1 & 20212.95 & $\begin{array}{c}1.07 \times \\
10^{9}\end{array}$ & $\begin{array}{c}1.03 \times \\
10^{9}\end{array}$ & $\begin{array}{c}1.30 \times \\
10^{9}\end{array}$ & $\begin{array}{c}1.75 \times \\
10^{9}\end{array}$ & $\begin{array}{c}1.54 \times \\
10^{9}\end{array}$ & $\begin{array}{c}1.70 \times \\
10^{9}\end{array}$ \\
\hline Median & $\begin{array}{c}1.93 \times \\
10^{9}\end{array}$ & $\begin{array}{c}2.05 \times \\
10^{9}\end{array}$ & 43077.28 & 28287.12 & 105815.8 & 19847.25 & $\begin{array}{c}1.07 \times \\
10^{9}\end{array}$ & $\begin{array}{c}9.95 \times \\
10^{8}\end{array}$ & $\begin{array}{c}1.25 \times \\
10^{9}\end{array}$ & $\begin{array}{c}1.73 \times \\
10^{9}\end{array}$ & $\begin{array}{c}1.53 \times \\
10^{9}\end{array}$ & $\begin{array}{c}1.66 \times \\
10^{9}\end{array}$ \\
\hline Maximum & $\begin{array}{c}2.76 \times \\
10^{9}\end{array}$ & $\begin{array}{c}3.11 \times \\
10^{9}\end{array}$ & 59717.50 & 39736.70 & 149370.0 & 24519.80 & $\begin{array}{c}1.64 \times \\
10^{9}\end{array}$ & $\begin{array}{c}1.54 \times \\
10^{9}\end{array}$ & $\begin{array}{c}2.09 \times \\
10^{9}\end{array}$ & $\begin{array}{c}2.70 \times \\
10^{9}\end{array}$ & $\begin{array}{c}2.07 \times \\
10^{9}\end{array}$ & $\begin{array}{c}2.41 \times \\
10^{9}\end{array}$ \\
\hline Minimum & $\begin{array}{c}9.43 \times \\
10^{8}\end{array}$ & $\begin{array}{c}1.06 \times \\
10^{9}\end{array}$ & 35709.70 & 21824.70 & 83124.00 & 15729.10 & $\begin{array}{c}5.13 \times \\
10^{8}\end{array}$ & $\begin{array}{c}5.95 \times \\
10^{8}\end{array}$ & $\begin{array}{c}7.32 \times \\
10^{8}\end{array}$ & $\begin{array}{c}9.16 \times \\
10^{8}\end{array}$ & $\begin{array}{c}8.82 \times \\
10^{8}\end{array}$ & $\begin{array}{c}8.88 \times \\
10^{8}\end{array}$ \\
\hline Std. Dev. & $\begin{array}{c}3.79 \times \\
10^{8}\end{array}$ & $\begin{array}{c}4.01 \times \\
10^{8}\end{array}$ & 6567.034 & 4464.640 & 15915.34 & 2242.631 & $\begin{array}{c}2.51 \times \\
10^{9}\end{array}$ & $\begin{array}{c}2.05 \times \\
10^{8}\end{array}$ & $\begin{array}{c}2.57 \times \\
10^{8}\end{array}$ & $\begin{array}{c}4.18 \times \\
10^{8}\end{array}$ & $\begin{array}{c}2.06 \times \\
10^{8}\end{array}$ & $\begin{array}{c}3.08 \times \\
10^{8}\end{array}$ \\
\hline Skewness & -0.028675 & 0.247034 & 0.557008 & 0.418314 & 0.453828 & 0.234630 & 0.152966 & 0.346598 & 0.521377 & 0.202849 & -0.118933 & 0.333384 \\
\hline Kurtosis & 2.379191 & 2.704042 & 1.889022 & 2.056739 & 2.137247 & 2.060440 & 2.261423 & 2.362579 & 2.756261 & 2.046231 & 3.856148 & 2.735795 \\
\hline $\begin{array}{l}\text { Jarque- } \\
\text { Bera }\end{array}$ & 2.202593 & 1.879607 & 14.02673 & 9.008228 & 8.886357 & 6.250211 & 3.621519 & 5.025353 & 6.498219 & 6.087508 & 4.474229 & 2.914844 \\
\hline Probability & 0.332440 & 0.390705 & 0.000900 & 0.011063 & 0.011759 & 0.043932 & 0.163530 & 0.081051 & 0.038809 & 0.047656 & 0.106766 & 0.232836 \\
\hline Sum & $\begin{array}{c}2.57 \times \\
10^{11}\end{array}$ & $\begin{array}{c}2.78 \times \\
10^{8}\end{array}$ & 6231668. & 3998245. & 15007747 & 2748962 & $\begin{array}{c}1.46 \times \\
10^{11}\end{array}$ & $\begin{array}{c}1.40 \times \\
10^{11}\end{array}$ & $\begin{array}{c}1.77 \times \\
10^{11}\end{array}$ & $\begin{array}{c}2.38 \times \\
10^{11}\end{array}$ & $\begin{array}{c}2.09 \times \\
10^{11}\end{array}$ & $\begin{array}{c}2.31 \times \\
10^{11}\end{array}$ \\
\hline $\begin{array}{c}\text { Sum Sq. } \\
\text { Dev. }\end{array}$ & $\begin{array}{c}1.93 \times \\
10^{19}\end{array}$ & $\begin{array}{c}2.17 \times \\
10^{19}\end{array}$ & $\begin{array}{c}5.82 \times \\
10^{9}\end{array}$ & $\begin{array}{c}2.69 \times \\
10^{9}\end{array}$ & $\begin{array}{c}3.42 \times \\
10^{10}\end{array}$ & $\begin{array}{c}6.79 \times \\
10^{9}\end{array}$ & $\begin{array}{c}8.51 \times \\
10^{18}\end{array}$ & $\begin{array}{c}5.67 \times \\
10^{18}\end{array}$ & $\begin{array}{c}8.89 \times \\
10^{18}\end{array}$ & $\begin{array}{c}2.36 \times \\
10^{19}\end{array}$ & $\begin{array}{c}5.72 \times \\
10^{18}\end{array}$ & $\begin{array}{c}1.28 \times \\
10^{19}\end{array}$ \\
\hline \multirow[t]{2}{*}{ Observations } & 136 & 136 & 136 & 136 & 136 & 136 & 136 & 136 & 136 & 136 & 136 & 136 \\
\hline & RBSK & RBPL & RBHU & RBCZ & & & & & & & & \\
\hline Mean & 99.97434 & 93.88132 & 92.09640 & 96.49971 & & & & & & & & \\
\hline Median & 100.0200 & 92.74000 & 90.44000 & 97.89000 & & & & & & & & \\
\hline Maximum & 103.2700 & 103.5000 & 105.6000 & 103.4800 & & & & & & & & \\
\hline Minimum & 96.19000 & 86.31000 & 82.89000 & 86.34000 & & & & & & & & \\
\hline Std. Dev. & 1.675818 & 3.932823 & 5.328271 & 4.651833 & & & & & & & & \\
\hline Skewness & -0.126680 & 0.577433 & 0.726260 & -0.424374 & & & & & & & & \\
\hline Kurtosis & 2.217122 & 2.790255 & 2.737809 & 1.933715 & & & & & & & & \\
\hline Observations & 136 & 136 & 136 & 136 & & & & & & & & \\
\hline
\end{tabular}




\section{Appendix B}

Table A2. HungaryARDL $(1,0,0,0,0,0)$ Model Result of Import.

Dynamic regressors (4 lags, automatic): LGDPCZ LGDPHU LGDPPL

LGDPSL RBHU_SA

Fixed regressors: D1 D2 C

Number of models evaluated: 12,500

Selected Model: ARDL $(1,0,0,0,0,0)$

Note: the final equation sample is larger than the selection sample

HAC standard errors \& covariance (Bartlettkernel, Newey-West fixedbandwidth $=5.0000$ )

\begin{tabular}{|c|c|c|c|c|}
\hline Variable & Coefficient & Std. Error & t-Statistic & Prob. * \\
\hline LHV4M(-1) & 0.395117 & 0.083749 & 4.717884 & 0.0000 \\
\hline LGDPCZ & -0.369892 & 0.149809 & -2.469093 & 0.0149 \\
\hline LGDPHU & 0.109075 & 0.339428 & 0.321350 & 0.7485 \\
\hline LGDPPL & 0.504661 & 0.238248 & 2.118216 & 0.0361 \\
\hline LGDPSL & 0.856577 & 0.278587 & 3.074715 & 0.0026 \\
\hline RBHU_SA & -0.002488 & 0.001661 & -1.498451 & 0.1365 \\
\hline $\mathrm{D} 1$ & -0.020137 & 0.024224 & -0.831287 & 0.4074 \\
\hline D2 & -0.384715 & 0.025883 & -14.86373 & 0.0000 \\
\hline $\mathrm{C}$ & 1.301452 & 1.287160 & 1.011104 & 0.3139 \\
\hline R-squared & 0.946900 & \multicolumn{2}{|c|}{ Mean dependent var } & 20.77306 \\
\hline $\begin{array}{l}\text { Adjusted } \\
\text { R-squared }\end{array}$ & 0.943528 & \multicolumn{2}{|c|}{ S.D. dependent var } & 0.224563 \\
\hline S.E. of regression & 0.053365 & \multicolumn{2}{|c|}{ Akaike info criterion } & -2.958995 \\
\hline $\begin{array}{l}\text { Sum squared } \\
\text { resid }\end{array}$ & 0.358821 & \multicolumn{2}{|c|}{ Schwarz criterion } & -2.765310 \\
\hline Log likelihood & 208.7322 & \multirow{3}{*}{\multicolumn{2}{|c|}{$\begin{array}{l}\text { Hannan-Quinn criter. } \\
\text { Durbin-Watson stat }\end{array}$}} & -2.880287 \\
\hline F-statistic & 280.8581 & & & 2.323251 \\
\hline Prob(F-statistic) & 0.000000 & & & \\
\hline
\end{tabular}

\section{Appendix C}

Table A3. Stable Import Model of Slovakia (D1 is Omitted).

\begin{tabular}{ccccc}
\hline \multicolumn{5}{c}{ Conditional Error Correction Regression } \\
\hline Variable & Coefficient & Std. Error & t-Statistic & Prob. \\
\hline C & 3.779677 & 0.884130 & 4.275027 & 0.0000 \\
LSV4M(-1) & -0.556579 & 0.088913 & -6.259783 & 0.0000 \\
LGDPCZ & 0.551319 & 0.152160 & 3.623285 & 0.0004 \\
LGDPHU(-1) & -0.593103 & 0.275773 & -2.150694 & 0.0335 \\
LGDPPL & 0.202979 & 0.261024 & 0.777626 & 0.4383 \\
LGDPSK & 0.609452 & 0.253242 & 2.406604 & 0.0176 \\
RBSL_SA & -0.001634 & 0.002979 & -0.548647 & 0.5843 \\
D(LSV4M(-1) & -0.347414 & 0.082416 & -4.215375 & 0.0000 \\
D(LSV4M(-2)) & -0.240092 & 0.065003 & -3.693552 & 0.0003 \\
D(LGDPHU) & -1.702735 & 0.539108 & -3.158428 & 0.0020 \\
D(LGDPHU(-1)) & 2.681293 & 0.474414 & 5.651802 & 0.0000 \\
D2 & -0.288259 & 0.051024 & -5.649519 & 0.0000 \\
\hline
\end{tabular}




\section{Appendix D}

Table A4. ARDL Model for Hungary (Newey-West HAC standard errors).

\begin{tabular}{|c|c|c|c|c|}
\hline \multicolumn{5}{|c|}{ Note: final equation sample is larger than selection sample } \\
\hline \multicolumn{5}{|c|}{ HAC standard errors \& covariance (Bartlettkernel, Newey-West fixed bandwidth = 5.0000) } \\
\hline Variable & Coefficient & Std. Error & t-Statistic & Prob. * \\
\hline LSV4X(-1) & 0.289023 & 0.080084 & 3.608984 & 0.0004 \\
\hline LSV4X(-2) & 0.170777 & 0.070597 & 2.419043 & 0.0171 \\
\hline LSV4X(-3) & 0.308876 & 0.064267 & 4.806151 & 0.0000 \\
\hline LGDPCZ & 0.366410 & 0.087446 & 4.190130 & 0.0001 \\
\hline LGDPHU & -1.102379 & 0.390665 & -2.821801 & 0.0056 \\
\hline LGDPHU(-1) & 2.456976 & 0.760887 & 3.229093 & 0.0016 \\
\hline LGDPHU(-2) & -2.086027 & 0.448411 & -4.652045 & 0.0000 \\
\hline LGDPPL & 0.539945 & 0.200524 & 2.692672 & 0.0081 \\
\hline LGDPSK & -0.055806 & 0.221300 & -0.252174 & 0.8013 \\
\hline RBSL_SA & -0.001917 & 0.002190 & -0.875366 & 0.3831 \\
\hline D1 & 0.012884 & 0.024794 & 0.519661 & 0.6043 \\
\hline D2 & -0.329631 & 0.030091 & -10.95457 & 0.0000 \\
\hline $\mathrm{C}$ & 2.965204 & 0.856284 & 3.462874 & 0.0007 \\
\hline R-squared & 0.838798 & \multicolumn{2}{|c|}{ Mean dependent var } & 21.15684 \\
\hline $\begin{array}{l}\text { Adjusted } \\
\text { R-squared }\end{array}$ & 0.822678 & \multicolumn{2}{|c|}{ S.D. dependent var } & 0.100733 \\
\hline S.E. of regression & 0.042418 & \multicolumn{2}{|c|}{ Akaike info criterion } & -3.389850 \\
\hline $\begin{array}{l}\text { Sum squared } \\
\text { resid. }\end{array}$ & 0.215916 & \multicolumn{2}{|c|}{ Schwarz criterion } & -3.107335 \\
\hline Log likelihood & 238.4250 & \multirow{3}{*}{\multicolumn{2}{|c|}{$\begin{array}{l}\text { Hannan-Quinn criter. } \\
\text { Durbin-Watson stat }\end{array}$}} & -3.275047 \\
\hline F-statistic & 52.03401 & & & 2.242319 \\
\hline Prob(F-statistic) & 0.000000 & & & \\
\hline
\end{tabular}

\section{Notes}

Visegrad Group History. https:/ / www.visegradgroup.eu/historie/historie-v4 (accessed on 15 November 2021).

For example, PV4M seasonally adjusted and the abbreviation would be PV4MSA. After performing the logarithmic transformation, the log (PV4MSA) has been labelled as LPV4M.

\section{References}

Anand, Paul, Bob Ferrer, Qin Gao, Ricardo Nogales, and Ellaine Unterhalter. 2020. COVID-19 as a capability crisis: Using the capability framework to understand policy challenges. Journal of Human Development and Capabilities 21: 293-99. [CrossRef]

Astrov, Vasily, and Mario Holzner. 2021. The Visegrad Countries: Coronavirus Pandemic, EU Transfers, and Their Impact on Austria, Policy Notes and Reports, No. 43. Vienna: The Vienna Institute for International Economic Studies.

Babunek, Ondřej. 2012. Foreign direct investment in Visegrad four and the main trading partners. Statistika-Statistics and Economy Journal 49: 14-26.

Bahmani-Oskooee, Mohsen, and Margaret Malixi. 1992. More evidence on the J curve from LDCs. Journal of Policy Modeling 14: 641-53. [CrossRef]

Barbero, Javier, Juan Jose de Lucio, and Ernesto Rodríguez-Crespo. 2021. Effects of COVID-19 on trade flows: Measuring their impact through government policy responses. PLOS ONE 16: e0258356. [CrossRef] [PubMed]

Bardi, Wajdi, and Mohammed Ali Hfaiedh. 2021. International trade and economic growth: Evidence from a panel ARDL-PMG approach. International Economics and Economic Policy 18: 847-68. [CrossRef]

Brüggemann, Ralf, and Helmut Lütkepohl. 2006. A small monetary system for the euro area based on German data. Journal of Applied Econometrics 21: 683-702. [CrossRef]

Cabada, Ladislav. 2018. Visegrad Group in the Context of Other Central European Cooperation Formats. Politics in Central Europe 13: 165-79. [CrossRef]

Cabada, Ladislav, and Šárka Waisová. 2018. The Visegrad Four as an ambitious actor of (Central-) European foreign and security policy. Politics in Central Europe 13: 9-20. [CrossRef]

Curto, José Dias, and Pedro Serrasqueiro. 2021. The impact of COVID-19 on S\&P500 sector indices and FATANG stocks volatility: An expanded APARCH model. Finance Research Letters, 102247. [CrossRef] 
Cvik, Eva Daniela, and Radka MacGregor Pelikánová. 2021. The significance of CSR during COVID-19 Pandemic in the Luxury Fashion Industry-A Front-Line Case Study. European Journal of Business Science and Technology 7: 109-29. [CrossRef]

Czech, Katarzyna, Michael Wielechowski, Pavel Kotyza, Irena Benešová, and Adriana Laputková. 2020. Shaking stability: COVID-19 impact on the Visegrad Group countries' financial markets. Sustainability 12: 6282. [CrossRef]

Dao, Phong. 2021. A CUSUM-Based Approach for Condition Monitoring and Fault Diagnosis of Wind Turbines. Energies 14: 3236. [CrossRef]

de Liedekerke, Arthur. 2015. Political Cacophony in the East: Visegrad Fraying at the Seams. Yale Journal of International Affairs 10: 85.

Dogan, Eyup, and Berna Turkekul. 2016. $\mathrm{CO}_{2}$ emissions, realoutput, energy consumption, trade, urbanization and financial development: Testing the EKC hypothesis for the USA. Environmental Science and Pollution Research 23: 1203-13. [CrossRef] [PubMed]

Ec.europa.eu. 2021. 2.24. Hungary. Available online: https:/ /ec.europa.eu/economy_finance/forecasts/2020/summer/ecfin_forecast_ summer_2020_hu_en.pdf (accessed on 15 November 2021).

Erokhin, Vasilii, and Tianming Gao. 2020. Impacts of COVID-19 on Trade and Economic Aspects of Food Security: Evidence from 45 Developing Countries. International Journal of Environmental Research and Public Health 17: 5775. [CrossRef]

Espitia, Alvaro, Aaditya Mattoo, Nadia Rocha, Michele Ruta, and Deborah Winkler. 2021. Pandemic trade: COVID-19, remote work and global value chains. The World Economy, 1-29. [CrossRef]

Farhani, Sahbi, and Ilhan Ozturk. 2015. Causal relationship between $\mathrm{CO}_{2}$ emissions, real GDP, energy consumption, financial development, trade openness, and urbanization in Tunisia. Environmental Science and Pollution Research 22: 15663-76. [CrossRef]

Fu, Mengyao, and Huayu Shen. 2020. COVID-19 and Corporate Performance in the Energy Industry. Energy Research Letters 1: 12967. [CrossRef]

Fuinhas, Jose Alberto, and Antonio Cardoso Marques. 2012. Energy consumption and economic growth nexus in Portugal, Italy, Greece, Spain, and Turkey: An ARDL bounds test approach (1965-2009). Energy Economics 34: 511-17. [CrossRef]

Grimes, Arthur. 2006. A smooth ride: Terms of trade, volatility and GDP growth. Journal of Asian Economics 17: 583-600. [CrossRef]

Grzybowski, Kazimierz. 1971. The Foreign Trade Regime in the Comecon Countries Today. NYU Journal of International Law and Politics 4: 183.

Gujarati, Damodar, and Dawn Porter. 2009. Basic Econometrics. Boston: McGraw-Hill.

Halicioglu, Ferda. 2008. The J-curve dynamics of Turkey: An application of ARDL model. Applied Economics 40: 2423-29. [CrossRef]

Hanus, Lubos, and Lukas Vácha. 2020. Growth cycle synchronization of the Visegrad Four and the European Union. Empirical Economics 58: 1779-95. [CrossRef]

Hayakawa, Kazunobu, and Hiroshi Mukunoki. 2021. Impacts of COVID-19 on Global Value Chains. The Developing Economies 59: 154-77. [CrossRef] [PubMed]

Heberle, Jochen, and Cristina Sattarhoff. 2017. A Fast Algorithm for the Computation of HAC Covariance Matrix Estimators. Econometrics 5: 9. [CrossRef]

Henderson, Karen. 2005. Back to Europe: Central and Eastern Europe and the European Union. London: Routledge.

International Monetary Fund (IMF). 2021. Policy Responses to COVID-19. Available online: https://www.imf.org/en/Topics/imfand-covid19/Policy-Responsesto-COVID-19 (accessed on 19 November 2021).

Iyke, Bernard Njindan. 2020. Economic Policy Uncertainty in Times of COVID-19 Pandemic. Asian Economics Letters. [CrossRef]

Jaraczewski. 2021. Jakub: An Emergency by Any Other Name? Measures against the COVID-19 Pandemic in Poland, VerfBlog. April 24. Available online: https://verfassungsblog.de/an-emergency-by-any-other-name-measures-against-the-covid-19-pandemicin-poland/ (accessed on 15 December 2021).

Jindřichovská, Irena, and Erginbay Uğurlu. 2021. EU and China trends in trade in challenging times. Journal of Risk and Financial Management 14: 71. [CrossRef]

Johansen, Soren, and Katarina Juselius. 1990. Maximum likelihood estimation and inference on cointegration with application to money demand. Oxford Bulletin Economics Statistics 52: 169-210. [CrossRef]

Karam, Fida, and Chair Zaki. 2015. Trade volume and economic growth in the MENA region: Goods or services? Economic Model 45: 22-37. [CrossRef]

Kazharski, Aliaksei. 2020. An ad hoc Regionalism? The Visegrad Four in the "Post-Liberal" Age. Polity 52: 250-72. [CrossRef]

Klasra, Mushtaq. 2011. Foreign direct investment, trade openness and economic growth in Pakistan and Turkey: An investigation using bounds test. Qual Quant 45: 223-31. [CrossRef]

Kong, Qunxi, Peng Dan, Ni Yehui, Jiang Xinyue, and Wang Ziqi. 2021. Trade openness and economic growth quality of China: Empirical analysis using ARDL model. Finance Research Letters 38: 101488. [CrossRef]

Kowalska, Anna, Klaudia Gurkowa, Anna Olszańka, Ivan Soukal, and Martin Matejicek. 2021. Assessment of the Competitive Position of the V4 Group Countries in the Foreign Trade of Agri-food Industry Products. In Proceedings of the International Scientific Conference Hradec Economic Days 2021. Edited by Maci Jan. Hradec Kralove: University of Hradec Kralove, vol. 11, pp. 449-70. ISBN 9788074358227. [CrossRef]

Lacka, Irena, Janusz Myszczyszyn, Sylwia Golab, Beata Bedzik, and Blazej Supron. 2020. Correlation between the Level of Economic Growth and foreign trade: The Case of the V4 Countries. European Research Studies Journal XXIII: 657-78.

Lutkepohl, Helmut, Pentti Saikkonen, and Carsten Trenkler. 2004. Testing for the Cointegrating Rank of a VAR Process with Level Shift at Unknown Time. Econometrica 72: 647-62. [CrossRef] 
MacGregor Pelikánová, Radka, and Martin Hála. 2021. CSR Unconscious Consumption by Generation Z in the COVID-19 eraResponsible Hereticsnot Paying CSR Bonus? Journal of Risk and Financial Management 14: 390. [CrossRef]

Mangir, Fatih, Esra Kabaklarl1, and Fatih Ayhan. 2017. An analysis for the relationship between trade openness and economic growth: Evidence for ten African countries. Journal of Management and Economics Research 15: 58-71. [CrossRef]

Mazur, Grzegorz, and Jakub Banach. 2021. V4 \& Development Co-operation Policy. Open Political Science 4: 180-93.

Narayan, Paresh, and Russell Smyth. 2005. Trade Liberalization and Economic Growth in Fiji. An Empirical Assessment Using the ARDL Approach. Journal of the Asia Pacific Economy 10: 96-115. [CrossRef]

Newey, Whitney, and Kenneth West. 1987. A simple, positive semi-definite, heteroskedasticity and autocorrelation consistent covariance matrix. Econometrica 55: 703-8. [CrossRef]

Pesaran, Hashem, and Bahram Pesaran. 1997. Working with Microfit 4.0: Interactive Econometric Analysis. Oxford: Oxford University Press.

Pesaran, Hashem, and Yongcheol Shin. 1999. An autoregressive distributed lag modelling approach to cointegration analysis. In Econometrics and Economic Theory in the 20th Century: The Ragnar Frisch Centennial Symposium. Edited by Steinar Strøm. Cambridge: Cambridge University Press.

Pesaran, Hashem, Yongcheol Shin, and Richard J. Smith. 2001. Bounds testing approaches to the analysis of level relationship. Journal of Applied Economics 16: 289-326. [CrossRef]

Richter, Sandor. 2012. Changes in the Structure of Intra-Visegrad Trade after the Visegrad Countries' Accession to the European Union (No. 5). Wiiw Statistical Report. Vienna: The Vienna Institute for International Economic Studies (wiiw).

Rose, Andrew. 1990. Exchange rates and the trade balance: Some evidence from developing countries. Economics Letters 34: 271-75. [CrossRef]

Rose, Andrew, and Janet Yellen. 1989. Is there a J-curve? Journal of Monetary Economics 24: 53-68. [CrossRef]

Saglam, Metin, and Erginbay Ugurlu. 2013. Kamu Açıları, parasalbüyümeve Enflasyon İlişkisi: Türkiye Örneği (1983-2008) [The relationship between Public Deficit, monetary growth and inflation: The example of Turkey (1983-2008)]. Finans Politik E Ekonomik Yorumlar [Financial Political \& Economic Reviews] 50: 71-84.

Salamaga, Marcin. 2021. The use of Correspondence Analysis in the study of Foreign Divestment in the Visegrad Countries during the Coronavirus Crisis. Econometrics 25: 15-26. [CrossRef]

Schimmelfennig, Frank, and Ulrich Sedelmeier, eds. 2005. The Europeanization of Central and Eastern Europe. New York: Cornell University Press.

Smutka, Lubos, Miroslav Svatoš, Karel Tomšík, and Olga Ivanovna Sergienko. 2016. Foreign trade in agricultural products in the Czech Republic. Agricultural Economics 62: 9-25. [CrossRef]

Smutka, Lubos, Mansoor Maitah, and Miroslav Svatoš. 2018. Changes in the Czech agrarian foreign trade competitiveness-Different groups of partners' specifics. Agricultural Economics 64: 399-411. [CrossRef]

Solarin, Sakiru Adebola, and Muhammad Shahbaz. 2015. Natural gas consumption and economic growth: The role of foreign direct investment, capital formation and trade openness in Malaysia. Renewable and Sustainable Energy Reviews 42: 835-45. [CrossRef]

Svatoš, Miroslav, and Lubos Smutka. 2010. Development of agricultural foreign trade in the countries of Central Europe. Agricultural Economics 56: 163-75. [CrossRef]

Svatoš, Miroslav, and Lubos Smutka. 2012a. Development of agricultural trade and competitiveness of the commodity structures of individual countries of the Visegrad Group. Agricultural Economics 58: 222-38. [CrossRef]

Svatoš, Miroslav, and Lubos Smutka. 2012b. Development of agricultural trade of Visegrad group countries in relation to EU and third countries. AGRIS Online Papers in Economics and Informatics 4: 55-69.

Svatoš, Miroslav, Lubos Smutka, and Ondřej Miffek. 2010. Competitiveness of agrarian trade of EU-15 countries in comparison with new EU member states. Agricultural Economics 56: 569-82. [CrossRef]

Tinbergen, Jan, ed. 1962. An Analysis of World Trade Flows. In Shaping the World Economy. New York: Twentieth Century Fund.

Thomas, C. J. 1976. The Comecon: Catalyst for economic cooperation in Eastern Europe. Comparative and International Law Journal of Southern Africa 9: 315-35.

Ugurlu, Erginbay, and Irena Jindrichovska. 2019. Estimating gravity model in the Czech Republic: An empirical study of impact of IFRS on Czech international trade. European Research Studies Journal 22: 265-81. [CrossRef]

UNCTAD. 2021. Key Statistics and Trends in International Trade. 2020. Available online: https://unctad.org/system/files/officialdocument/ditctab2020d4_en.pdf (accessed on 15 December 2021).

Vidya, C. T., and K. P. Prabheesh. 2020. Implications of COVID-19 pandemic on the global trade networks. Emerging Markets Finance and Trade 56: 2408-21. [CrossRef]

Vlada.cz. 2021. Measures Adopted by the Czech Government against the Coronavirus. Available online: https:/ /www.vlada.cz/en/mediacentrum/aktualne/measures-adopted-by-the-czech-government-against-coronavirus-180545/ (accessed on 5 November 2021).

Vološin, Josef, Lubos Smutka, and Richard Selby. 2011. Analysis of external and internal influences on CR agrarian foreign trade. Agricultural Economics 57: 422-35. [CrossRef]

Waisová, Šárka. 2020. Central Europe in the New Millenium: The New Great Game? US, Russian and Chinese Activities in Czechia, Hungary, Poland, and Slovakia. Revista UNISCI, 29-48. [CrossRef] 